\title{
PHENOTYPIC CHARACTERIZATION AND MOLECULAR IDENTIFICATION OF SOME LACTIC ACID PRODUCING BACTERIA IN RAW MILK OF DIFFERENT ANIMAL SPECIES
}

\author{
HANAA A.E. ASFOUR ${ }^{1}$, INAS M. GAMAL ${ }^{2}$ and SAMAH F. DARWISH ${ }^{3}$ \\ ${ }^{1}$ Mastitis and Neonatal Diseases Department, Animal Reproduction Research Institute (ARRI), Giza, Egypt \\ ${ }^{2}$ Immunobiology and Immunopharmacology Unit, Animal Reproduction Research Institute (ARRI), Giza, Egypt \\ ${ }^{3}$ Biotechnology Research Unit, Animal Reproduction Research Institute (ARRI), Giza, Egypt
}

Received: 23 March 2016; Accepted: 6 April 2016

\begin{abstract}
A total number of 228 apparently healthy milk samples were collected from individual and bulk tank milk of cows (100 and 86 samples, respectively), goats (30) and she camel (12) for isolation of some lactic acid bacteria (LAB) especially that have coccal form. The preliminary screening LAB community at the genus level depending on the basis of morphological characteristics showed that, the isolates were differentiated into 4 groups; Enterococci, Leuconostocs, Pediococci and Streptococci with a total percentage of $61 \%$. The highest \% of LAB was recorded for Enterococcus species in the different animal species especially in camel milk (41.7\%). Antibacterial activity of selected $75 \mathrm{LAB}$ strains against $S$. aureus, S. uberis, E. coli and Yersinia enterocolotica as bovine mastitis pathogens were detected. 53 out of 75 of the selected strains showed antibacterial effect against the tested pathogens. Eighteen Enterococcus isolates have inhibitory effects on all of the tested bacteria with inhibition zone diameter ranged between 10-25 mm. Sodium dodecyl sulfate polyacrylamide gel electrophoresis (SDS-PAGE) was used as an aid step for identification of LAB strains. Thus the SDS-PAGE results confirmed the biochemical identification of the isolated cultures for Leuconostoc mesenteroides with a percentage of similarity (90.8\%), for Pediococcus acidilactici (92.5\%), for Enterococcus hirae (99.84\%) and for Streptococcus thermophilus $(99.89 \%)$. Representative strains of genus Enterococci that had higher antibacterial activity against mastitis pathogens were subjected to sequence-based identification. The obtained sequences of these isolates were submitted to the Gen Bank database with accession numbers KU847974 and KU847975 for E. faecium and E. hirae, respectively and showed $99 \%$ 16S rRNA sequence homology. It was concluded that raw animal milk may be a potential source for the isolation of probiotic LAB with antibacterial properties against mastitis pathogens that may be presented as an interesting alternative to antibiotic drugs to overcome the antibiotic resistance of mastitis pathogens as well as antibiotic residues in milk.
\end{abstract}

Key words: LAB; raw milk; isolation; identification; antibacterial activity; mastitis pathogens

\section{INTRODUCTION}

Probiotic products were proposed as a valid alternative to antibiotic therapies and are also useful for the prevention of infectious syndromes (Espeche et al., 2012).

Bacteria proposed for probiotic uses are usually categorized as lactic acid bacteria (LAB); commonly used bacteria include various species of Lactobacillus, Bifidobacterium and Streptococcus as well as some Enterococcus species (Morrow et al., 2012). LAB are one of the most representative groups

Corresponding author: Dr. HANAA A.E. ASFOUR

E-mail address: hanaaasfour@yahoo.com

Present address: Mastitis and Neonatal Diseases Department, Animal Reproduction Research Institute (ARRI), Giza, Egypt of prokaryotes used with this purpose and are part of the indigenous micro-biota of the teat canal. They are optimal candidates to design a species specific probiotic product to prevent bovine mastitis (Espeche et al., 2009 and Giannino et al., 2009). In the field of bovine health, probiotics were mainly applied to prevent gastrointestinal infections and for nutritional purposes (Rodriguez-Palacios et al., 2009 and Sun et al., 2010).

Lactic acid bacteria, in addition to their probiotic properties, impede the growth of pathogenic and spoiling bacteria by competing for nutrients and starter derived inhibitor compounds, such as lactic acid, hydrogen peroxide and bacteriocins (Stiles and Holzapfel, 1997) thereby technically improving the quality of the milk. Moreover, wild LAB strains represent a natural reservoir of strains not exposed to 
any industrial selection and are potential probiotics and bacteriocin producers (Guessas and Kihal, 2005).

Bacteriocins are gene-encoded inhibitory proteins and those produced by Gram-positive LAB are inhibitory mainly to other Gram-positive bacteria. Some bacteriocins even display antagonistic activity towards Gram-positive food borne pathogens and spoilage organisms (Knoll et al., 2008; Macwana and Muriana, 2012). The application of biotechnology to mastitis treatment is opening up new avenues of prevention and control. For mastitis treatment, bacteriocins can be either infused into the udder (in the same way as antibiotics), or used in solutions (such as teat dips). These proteins are larger molecules than antibiotics and are expected to persist in the udder longer. Unlike antibiotics, the rapid action of bacteriocins reduces the likelihood of an induced resistance in target and non target organisms (Miles et al., 1992).

According to some authors, the species-specificity is essential to favour the adhesion and expression of the beneficial effects (Nader-Macías et al., 2008). This presumption is based on ecologic issues, because autochthonous strains have higher chances to survive than others due to their previous adaptation to specific environments. Moreover, it was demonstrated by applying comparative genomics of $\mathrm{LAB}$, the existence of a niche-specific gene set which allow them to live in a specific environment but not in others (O'Sullivan et al., 2009).

The isolation of novel taxa mainly depends on the cultivation approach used selective incubation media and conditions. The biochemical and physiological tests are unsatisfactory for the identification of isolated LAB so that the identification of isolated strains needs a polyphasic approach, including a combination of phenotypic and genotypic methods. So SDS-PAGE of whole cell protein was widely used for identification of $\mathrm{LAB}$, since it offered the advantage to have a good level of taxonomic resolution at species and subspecies (De Vuyst and Vancanneyt, 2006; Ghazi et al., 2009).

Unfortunately, in Egypt little information exists on lactic acid micro-biota in raw animal milk, for this reason, the objectives of this study were to collect a variety of raw milk samples from different animal species in order to constitute original collection of LAB strains, to pre-select some strains according to their beneficial characteristics that can be used as a source of probiotics for some mastitis pathogens depending on their in vitro antimicrobial properties and to confirm them depending on their whole cell proteins fingerprinting and genetic taxonomic identification.

\section{MATERIALS AND METHODS}

1 - Collection of milk samples: a total number of 228 milk samples were collected from individual composite and bulk tank milk of cows (100 and 86 samples, respectively), goats (30) and she camel (12). Samples were taken under complete aseptic conditions from clinically healthy animals, as well as bulk tank milk, immediately refrigerated in ice box and transported to the laboratory.

\section{2 - Isolation of LAB:}

Isolation was done using De Man, Rogosa and Sharpe (MRS, with tween 80) agar plate media (Biolife, Milano, Italy). Plates were incubated anaerobically using the Gas Pack system for $24-72$ hours at $37^{\circ} \mathrm{C}$ under $5 \% \mathrm{CO} 2$ conditions followed by picking the distinguishable colonies by sterile loop (Patil et al., 2010). Macroscopic examination to describe the bacterial colonies on solid medium; their color, edge, elevation, aspect, pigmentation, opacity and diameter were done. Microscopic examination defined cell morphological appearance such as shape, pairing mode and type isolates of Gram staining were done. A total of 160 strains were isolated from four different animal species milk samples, which were observed as cocci in different forms. Isolation methods followed were similar to those recommended by Van den Berg et al. (1993). All the 160 cocci isolates were further cultured to obtain purity. Purification of the isolates was confirmed by Gram staining and pure isolated were maintained on MRS slope agar tubes at $4^{\circ} \mathrm{C}$ for further studies.

\section{3 - Culture Identification:}

Gram staining and catalase activity were observed with the selected isolates which led the researches on a way from where only 139 of the isolates with Gram positive and catalase negative results were short listed for further analysis following the scheme of Nikita and Hemangi, (2012). In this study we selected only the Gram positive, catalase negative cocci that were identified at genus level for the further tests including sugar fermentation, growth at different temperatures $\left(10,37\right.$ and $\left.45^{\circ} \mathrm{C}\right)$ and in $5 \% \mathrm{NaCl}$.

\section{4 - Preparation of Cell-Free Supernatants:}

Only 75 strains were selected on the bases of intensity of growth on both MRS agar and broth turbidity to be used for the rest of work. The selected strains for antimicrobial activity were incubated in MRS broth with tween 80 (Biolife, Milano, Italy) for $48 \mathrm{~h}$ at $37^{\circ} \mathrm{C}$ under anaerobic condition. Bacterial cells were removed by centrifuging the culture at $5000 \mathrm{~g}$ for 20 $\min$ at $4^{\circ} \mathrm{C}$. The $\mathrm{pH}$ values of supernatants were adjusted to $\mathrm{pH}$ 6.5-7.0 by the addition of $1 \mathrm{~N} \mathrm{NaOH}$. The supernatants were membrane filtered (Millipore, $0.22 \mu \mathrm{m}$ ) and stored at $4^{\circ} \mathrm{C}$ (Darsanaki et al., 2012). The bacterial cell pellets were subjected for detection of protein profile of the isolated strains using SDS. 
5 - Determination of the production of bacteriocinlike inhibitory substance by the lactic acid bacteria: Agar well diffusion method was used to detect antimicrobial activities of supernatants produced from the selected LAB strains and to determine their ability to produce bacteriocin-like inhibitory substances (Lyon and Glatz, 1993). The plates were poured with $20 \mathrm{ml}$ Mueller Hinton Agar M173 (Himedia, Mumbai, India). Pathogenic bacterial strains were previously isolated from mastitic bovine milk; 2 Gram positive pathogens ( $S$. aureus and S.uberis) and 2 Gram negative pathogens (E. coli and Yersinia enterocolotica) were adjusted to a density of $10^{8} \mathrm{CFU} / \mathrm{ml}$ (using McFarland tube 0.5) by adding sterile PBS and were spread on the surface of Mueller Hinton agar plates. Wells of $6 \mathrm{~mm}$ in diameter were cut into these agar plates and $100 \mu \mathrm{l}$ of the supernatants were placed into each well. The culture plates were incubated at $37^{\circ} \mathrm{C}$ for $24 \mathrm{~h}$ and the zones of inhibition were measured in diameter $(\mathrm{mm})$. The antimicrobial activity of the cell free supernatant was determined twice (i.e before and after neutralization of the supernatant to $\mathrm{pH} 6.5$ with $1 \mathrm{M}$ $\mathrm{NaOH})$ and the mean values were recorded.

\section{6 - Analysis of Lactic Acid bacteria using SDS:}

A- Characterization by SDS-PAGE analysis of the whole-cell protein:

The selected strains previously identified from their phenotypic characteristics were submitted to SDSPAGE of whole-cell proteins to confirm their results. Preparation of cell-free extracts and polyacrylamide gel electrophoresis were done as described by Pot et al. (1994). Identification of selected strains was performed by comparison of their protein patterns with a database of normalized protein fingerprints derived from reference strains.

\section{B- Computer-aided Analysis of the Gels:}

Images of the gels were captured using a Sharp JX330 flat-bed scanner, and image analysis of the protein profiles was performed using Amersham Pharmacia Biotech Image Master 2-D Elite software. The relative amount of each protein spot was calculated and expressed by the software as the percentage of the spot volume and represented the intensity of each individual spot compared to the intensity of the whole gel. The genetic similarity coefficient between two genotypes was estimated according to Dice. The similarity-derived dissimilarity matrix was used in the cluster analysis by using the un-weighted pair-group method with arithmetic averages (UPGMA).

7 - Identification of some isolates by $16 S \mathrm{rRNA}$ gene amplification, sequencing, and analysis:

The identification of some Enterococcus isolates were determined using PCR amplification with universal $16 \mathrm{~S}$ ribosomal RNA primers 8F 5'- AGA GTT TGA TCC TGG CTC AG- 3' and U1492R 5'- GGT TAC CTT GTT ACG ACT T- 3' as described by James (2010). DNA was isolated from pure cultures using ZR Fungal/Bacterial DNA Mini Prep ${ }^{\mathrm{TM}}$ kit (ZYMO RESEARCH). Thermal cycling was performed using a Nexus gradient Master cycler (Eppendorf, Germany) as described previously (James, 2010): initial denaturation at $95^{\circ} \mathrm{C}$ for $4 \mathrm{~min}$, followed by 30 cycles of $94{ }^{\circ} \mathrm{C}$ for $1 \mathrm{~min}$ (denaturation), $60{ }^{\circ} \mathrm{C}$ for 45 $\mathrm{s}$ (annealing), $72{ }^{\circ} \mathrm{C}$ for $1 \mathrm{~min}$ (extension), followed by a final extension cycle at $72{ }^{\circ} \mathrm{C}$ for $4 \mathrm{~min}$, and a final hold at $4{ }^{\circ} \mathrm{C}$. Amplimers of $16 \mathrm{~S}$ rRNA genes were purified using DNA Clean \& Concentrator ${ }^{\text {TM}}-25$ kits (ZYMO RESEARCH) according to the manufacturer's recommendations and eluted DNA was stored at $-20{ }^{\circ} \mathrm{C}$ until needed. The purified DNA was sequenced in an automated ABI 3730 DNA sequencer (Applied Biosystems, USA). ABI sequence files were analyzed using MEGA5 (The Biodesign Institute, Tempe, AZ, USA) by cutting out $5^{\prime}$ and $3^{\prime}$ regions of high background noise (Tamura et al., 2011). Consensus sequences were identified using NCBI's Nucleotide BLAST.

\section{RESULTS}

The LAB strains were sorted in the following table according to Aziz et al. (2009) and Abbasiliasi et al. (2012).

Table 1: Morphological characteristics of isolated LAB

\begin{tabular}{llccc}
\hline Characteristics & \multicolumn{4}{c}{ Cocci or coccoid } \\
\hline Colony surface & Smooth & Smooth & Slimy & Mucoid and glistening \\
\hline Colony size & small & small & medium & medium \\
\hline Colony margin & Entire & Entire & Undulate & Circular \\
\hline Colony color & White & White & White & Milky white \\
\hline Cell morphology & chains & chains & Chains/ pairs & pairs /tetracocci \\
\hline $\begin{array}{l}\text { Presumptive } \\
\text { identification }\end{array}$ & Enterococci & Streptococci & Leuconostocs & Pediococci \\
\hline
\end{tabular}

The morphological characters of each isolated LAB species showed in fig 1, 2,3 and 4. 

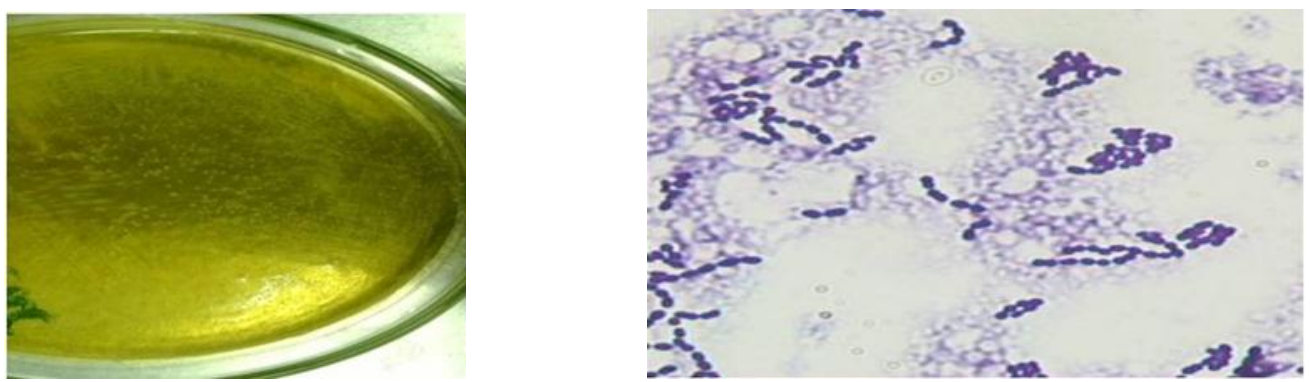

Fig. (1): Enterococci; macroscopic small white colonies on MRS agar medium that arranged in the form of Gram positive different chains of cocci (Enterococcus hirae) microscopically.
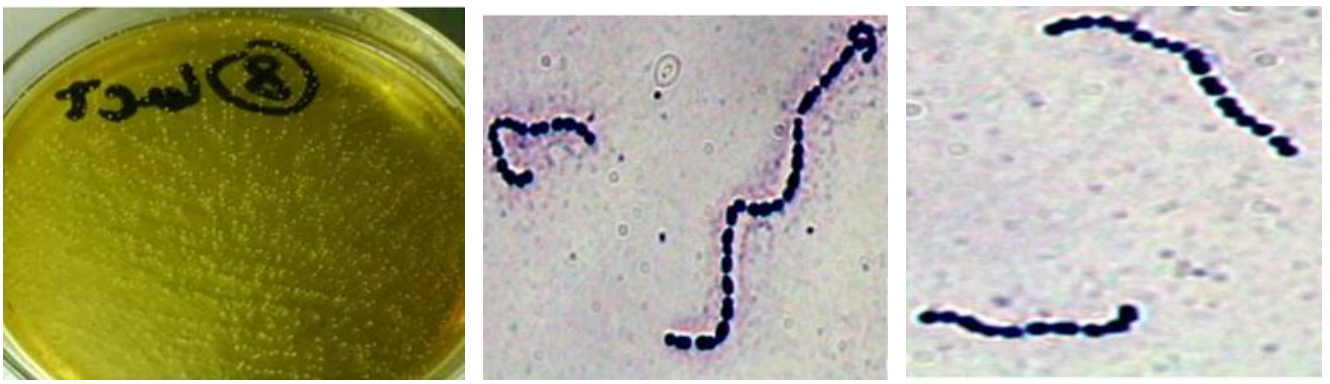

Fig. (2): Streptococci; macroscopic small white colonies on MRS agar that arranged in the form of Gram positive long chains of cocci (Streptococcus thermophillus) with exopolysaccharide layer appeared as hallows around the cocci microscopically.
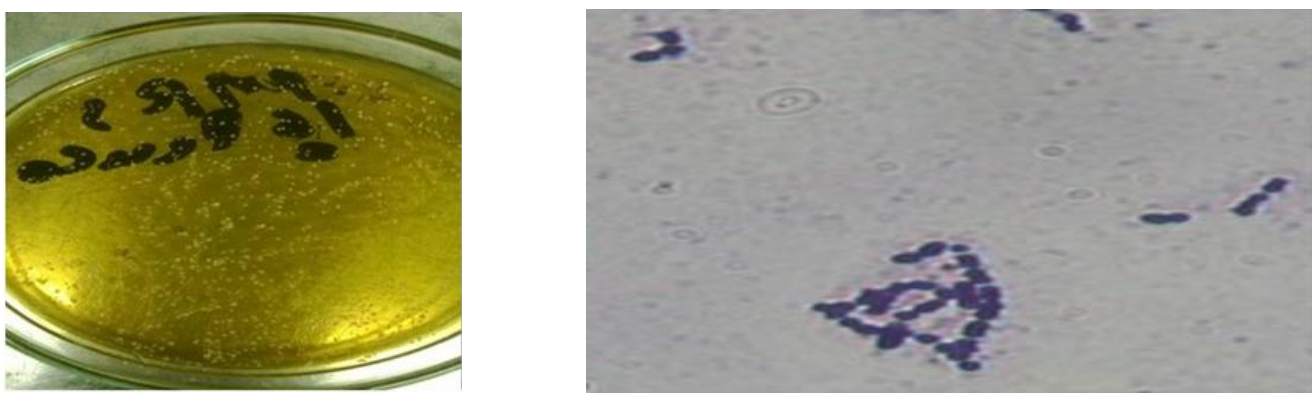

Fig. (3): Leuconostoc; macroscopic, slimy medium undulate white colonies on MRS agar that arranged in the form of Gram positive chains/ pairs of cocci or cocoids microscopically.
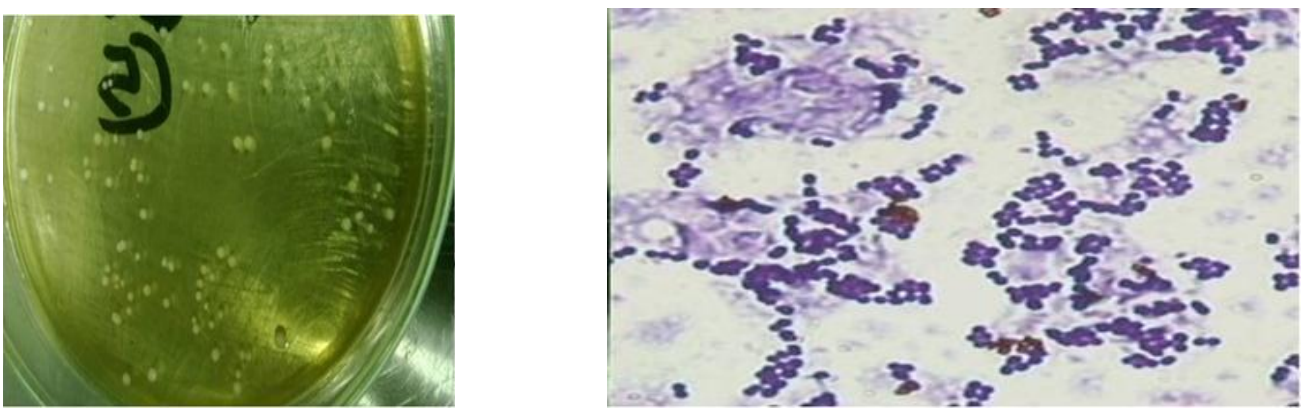

Fig. (4): Pediococcus; macroscopic mucoid, glistening white medium to large size colonies on MRS agar that arranged in the form of Gram positive chains/ pairs/tetracocci/grapes microscopically. 
Table 2: The distribution percentage of different genus of LAB in milk samples of different animal species based on their morphology.

\begin{tabular}{|c|c|c|c|c|c|c|}
\hline \multicolumn{2}{|c|}{ Milk samples } & \multicolumn{4}{|c|}{ Lactic acid bacteria (\%) } & \multirow{2}{*}{$\begin{array}{l}\text { Total isolation of } \\
\text { LAB form each } \\
\text { animal species }\end{array}$} \\
\hline & & Enterococci & Leuconostocs & Pediococci & Streptococci & \\
\hline \multirow[t]{2}{*}{ Cow } & $\begin{array}{l}\text { Individual milk } \\
\qquad(100)\end{array}$ & $20(20 \%)$ & - & $5(5 \%)$ & $5(5 \%)$ & $30(30 \%)$ \\
\hline & $\begin{array}{c}\text { Bulk tank milk } \\
\qquad(86)\end{array}$ & $46(53.5 \%)$ & $15(17.4 \%)$ & $15(17.5 \%)$ & $10(11.6 \%)$ & $86(100 \%)$ \\
\hline \multicolumn{2}{|c|}{ Goat milk (30) } & $8(26.6 \%)$ & $2(6.7 \%)$ & $3(10 \%)$ & $2(6.7 \%)$ & $15(50 \%)$ \\
\hline \multicolumn{2}{|c|}{ Camel milk (12) } & $5(41.7 \%)$ & $1(8.3 \%)$ & - & $2(16.7 \%)$ & $8(66.7 \%)$ \\
\hline \multicolumn{2}{|c|}{ Total (228) } & $79(34.7 \%)$ & $18(7.9 \%)$ & $23(10.1 \%)$ & $19(8.3 \%)$ & $139(61 \%)$ \\
\hline
\end{tabular}

Total \% was calculated according to total no. of the tested milk samples (228).

Table 3: Inhibition of the test pathogens by cell free supernatant of the isolated LAB strains (Diameter of inhibition zones measured in $\mathrm{mm}$ ).

\begin{tabular}{|c|c|c|c|c|}
\hline \multirow[b]{2}{*}{ Tested strains } & \multicolumn{4}{|c|}{ No. of LAB that have antibacterial activity and range of inhibition zone (mm) } \\
\hline & $\begin{array}{c}\text { Enterococci } \\
\text { (30) }\end{array}$ & $\begin{array}{l}\text { Leuconostocs } \\
\text { (15) }\end{array}$ & $\begin{array}{c}\text { Pediococci } \\
\text { (15) }\end{array}$ & $\begin{array}{c}\text { Streptococci } \\
\text { (15) }\end{array}$ \\
\hline S. aureus & $18(12-25)$ & $9(10-22)$ & $8(15-20)$ & $12(15-20)$ \\
\hline S. uberis & $21(16-25)$ & $7(15-18)$ & $8(13-20)$ & $9(15-20)$ \\
\hline E. coli & $20(10-20)$ & $10(10-19)$ & $8(10-13)$ & $10(10-13)$ \\
\hline $\begin{array}{l}\text { Yersinia } \\
\text { enterocolotica }\end{array}$ & $22(10-25)$ & $10(13-20)$ & $9(10-20)$ & $12(15-25)$ \\
\hline
\end{tabular}

Antibacterial activity of the selected LAB strains against S. aureus, S. uberis, E. coli and Yersinia enterocolotica were detected as shown in fig. (5).

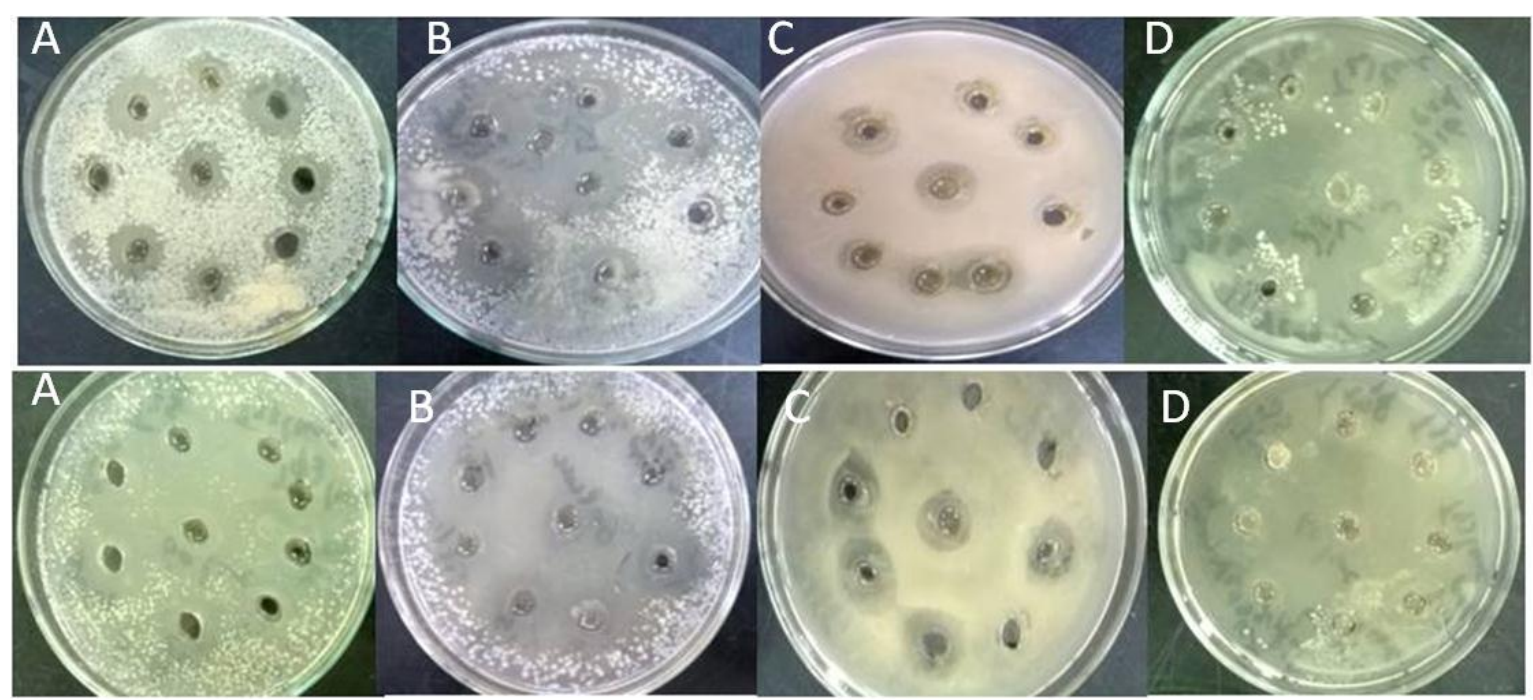
Fig. (5) A. against $S$. aureus
B. against $S$. uberis
C. against E. coli
D. against Yersinia enterocolotica 
Table 4: Phenotypic identification of the isolated LAB that produce bacteriocin like substances on the species level

\begin{tabular}{|c|c|c|c|c|c|c|}
\hline \multirow{4}{*}{$\begin{array}{l}\text { No. of } \\
\text { identified } \\
\text { species }\end{array}$} & \multicolumn{6}{|c|}{ Identification on genus and species levels } \\
\hline & \multicolumn{2}{|c|}{$\begin{array}{l}\text { Enterococci } \\
\qquad(22)\end{array}$} & $\begin{array}{l}\text { Leuconostocs } \\
\text { (10) }\end{array}$ & \multicolumn{2}{|c|}{$\begin{array}{l}\text { Pediococci } \\
\text { (9) }\end{array}$} & $\begin{array}{c}\text { Streptococci } \\
\text { (12) }\end{array}$ \\
\hline & $\begin{array}{c}\text { Enterococcus } \\
\text { hirae }\end{array}$ & $\begin{array}{c}\text { Enterococcus } \\
\text { faecium }\end{array}$ & $\begin{array}{l}\text { Leuconostoc } \\
\text { mesenteroides }\end{array}$ & $\begin{array}{c}\text { Pediococcus } \\
\text { acidilactici }\end{array}$ & $\begin{array}{l}\text { Pediococcus } \\
\text { pentosaceus }\end{array}$ & $\begin{array}{l}\text { Streptococcus } \\
\text { thermophilus }\end{array}$ \\
\hline & 14 & 8 & 10 & 5 & 4 & 12 \\
\hline Total (53) & & & 10 & & & 12 \\
\hline
\end{tabular}

Using the UPGMA clustering (Simple B and Match), protein patterns were compared with protein fingerprints of reference strains including the genera; Enterococcus, Leuconostoc, Pediococcus and Streptococcus thermophilus. The resulting dendrograms were shown in Figures 6,7,8 and 9.

According to the SDS-PAGE results, the biochemical identification of the isolated cultures was confirmed for all Enterococci, Leuconostocs, Pediococci and Streptococci. As the protein fingerprinting of the strains that were biochemically identified as
Leuconostoc mesenteroides showed a percentage of similarity (90.8\%) with the reference strain (Fig.6). At the same time, the protein fingerprinting of the strains that were biochemically identified as Pediococcus acidilactici were very similar to the reference strain with a percentage of $(92.5 \%)$ (Fig.7). On the other hand, the percentage of similarity between the strains that were biochemically identified as Streptococcus thermophilus was (99.89\%) (Fig.8). Meanwhile the strains that were biochemically identified as Enterococcus hirae have shown a high level of similarity with (99.84\%) (Fig.9).
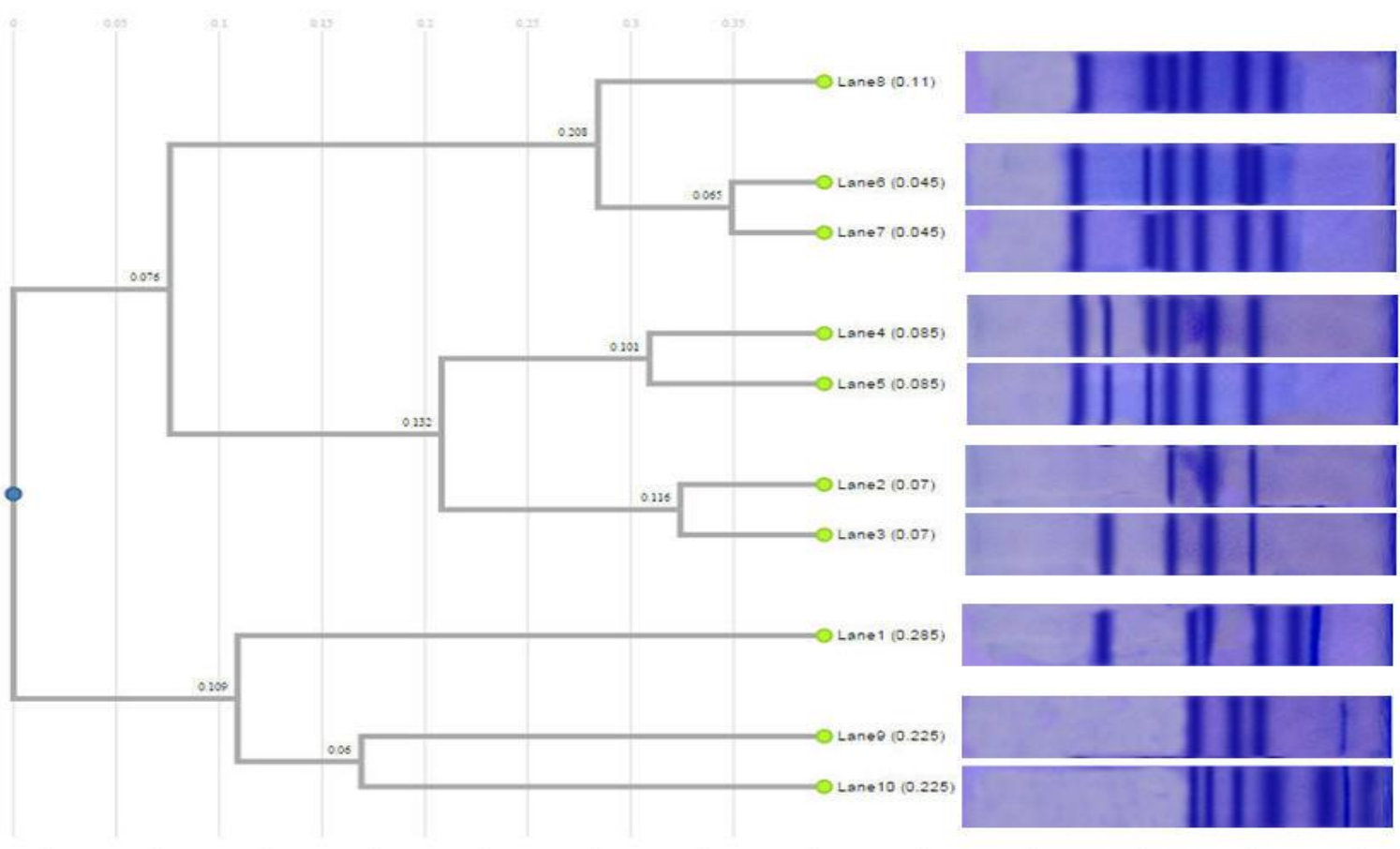

Fig. (6): Dendrogram analysis of the expressed Leuconostoc mesenteroides. 


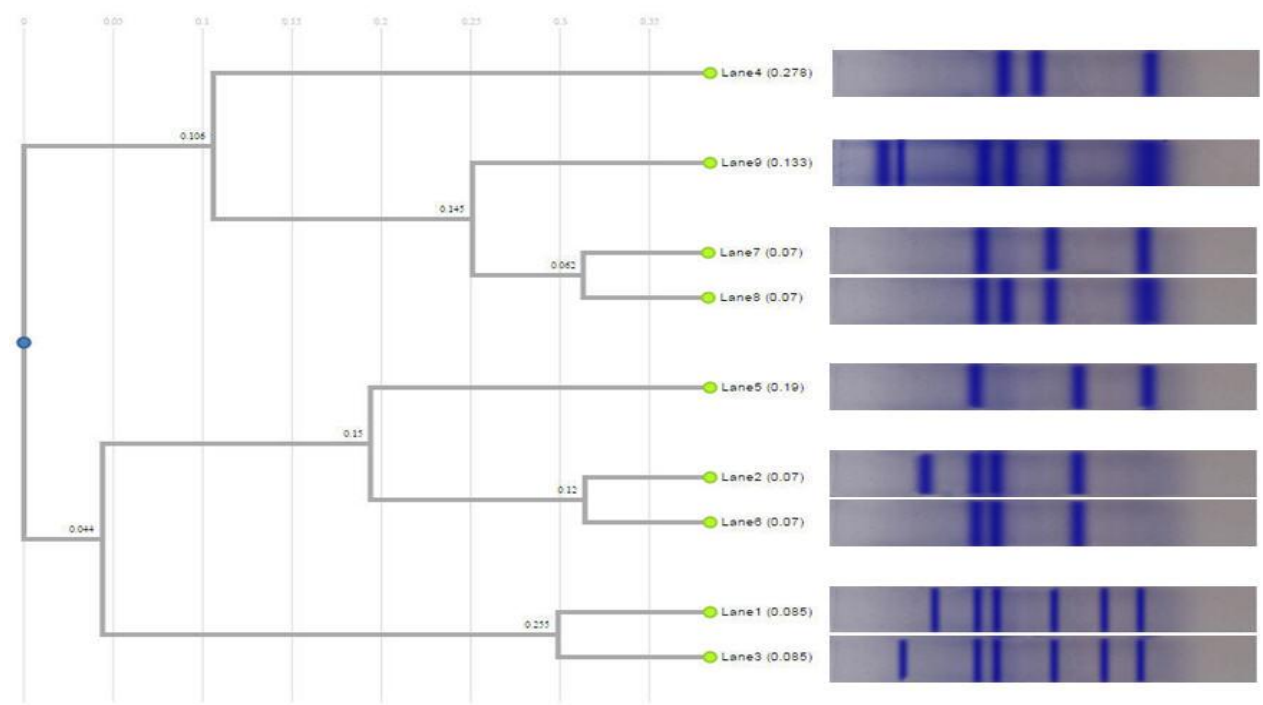

Fig. (7): Dendrogram analysis of the expressed Pediococcus acidilactici.

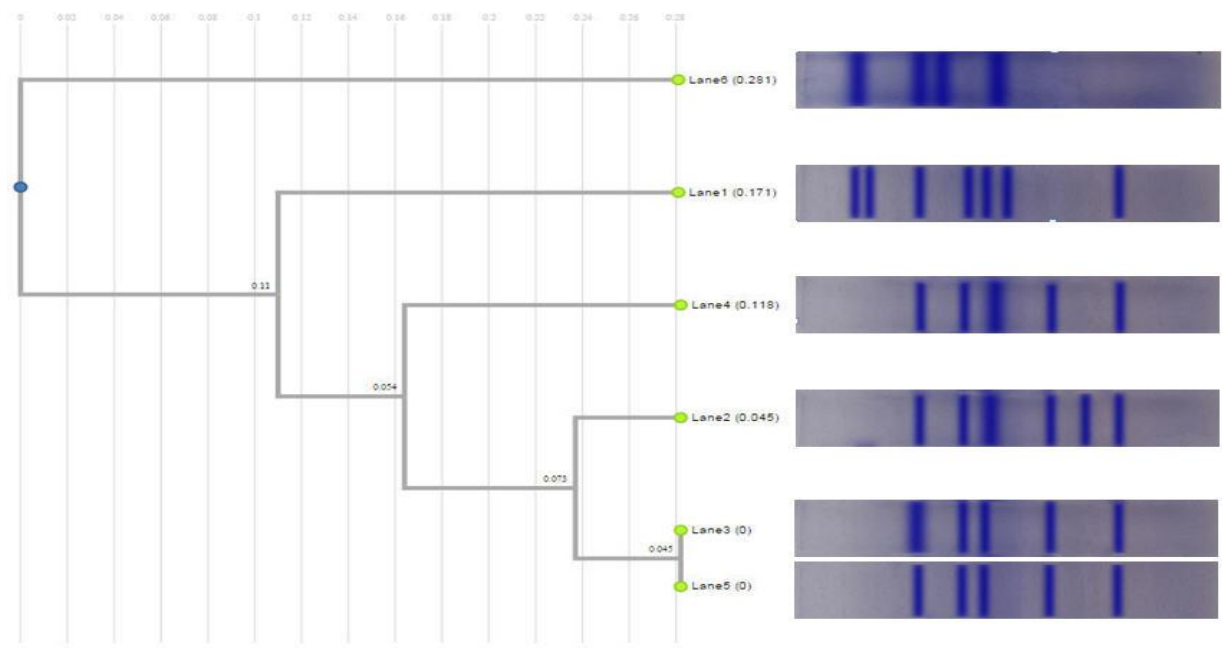

Fig. (8): Dendrogram analysis of the expressed streptococcus thermophilus.
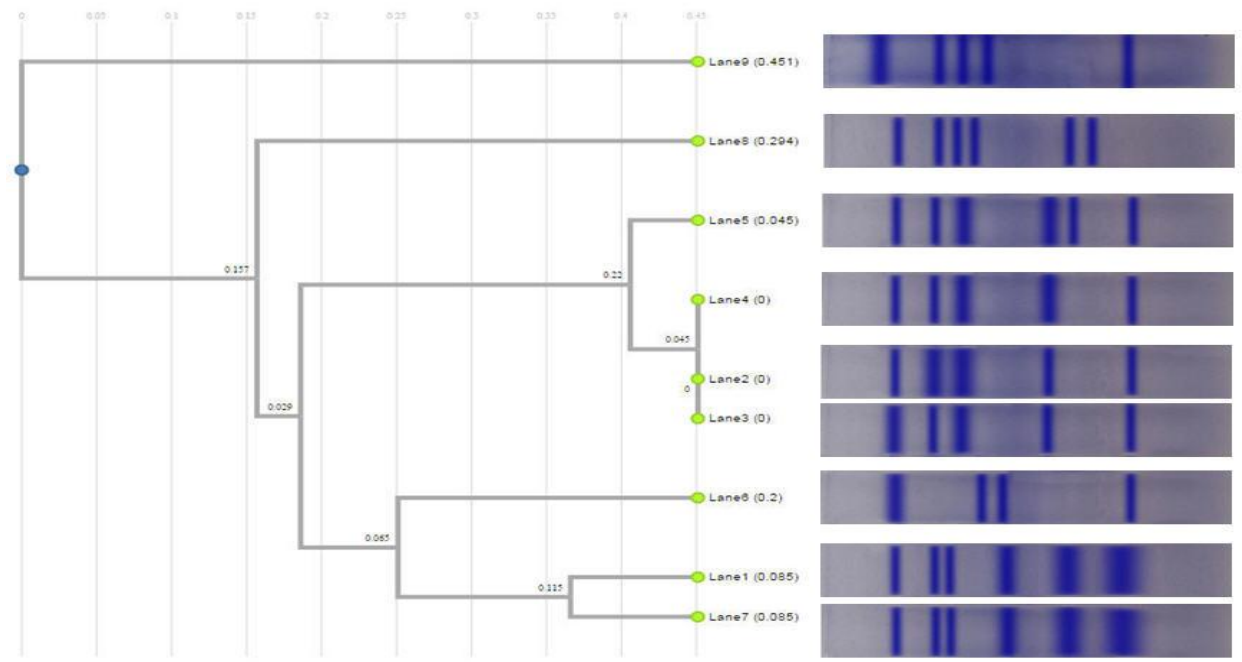

Fig. (9): Dendrogram analysis of the expressed Enterococcus hirae. 
Representative strains of Enterococci as the most isolated species were subjected to $16 \mathrm{~S}$ rRNA gene sequence analysis and the phylogenetic closest neighbors were determined. Sequencing of $16 \mathrm{~S}$ rRNA gene of the selected isolates was performed to further confirm the identities of the strains within each cluster. The obtained sequences of some isolates were submitted to the GenBank database with the following accession numbers KU847974 and KU847975 for E. faecium and E. hirae, respectively. A BLAST search of the 16S rRNA gene sequences obtained was then performed at NCBI revealing high similarity values to a number of sequences in the GenBank database. Strains identified as E. hirae and E. faecium showed $99 \% \quad 16 \mathrm{~S}$ rRNA sequence homology for each of them in the Gen- Bank database.

\section{DISCUSSION}

A variety of microorganisms including yeasts, molds and bacteria are present in raw milk. However, among these organisms, only lactic acid bacteria have the property of producing lactic acid from milk sugars by the process of fermentation and thus LAB constitute the predominant microflora of milk. These bacteria are responsible for most of the physiochemical and aromatic transformations intrinsic to fermented dairy products (Ogier et al., 2002).

With the aim of designing a probiotic product that can be used to control bovine mastitis, LAB were isolated from milk samples of different animal species including cows, goats and she camel. Total milk samples (228) were collected from cow (100 pool individual milk and 86 bulk tank milk), goats (30) and she camel (12). The preliminary screening of milk LAB community at the genus level depending on the basis of various morphological characteristics the isolates were differentiated into 4 groups, Enterococcus, Leuconostoc, Pediococcus and Streptococcus with a total percentage of $(61 \%)$ that was near to that accounted by Aziz et al. (2009) who found that the overall incidence of lactic bacteria in milk was $66 \%$ and the incidence of lactic isolates was the highest in cow milk $(75 \%)$ that agreed with the present results as LAB were isolated from cows' bulk tank milk that reached to $100 \%$ in the present study.

In goat milk $15 / 30$ coccus strains of $\mathrm{LAB}$ were isolated $(50 \%)$ this came in accordance with Silva et al. (2013) who found LAB were predominant in the raw goat milk and when selected, contribute to an increase in the functional value of goat milk.

In camel milk $8 / 12$ coccus strains of LAB were isolated with a percentage of $66.7 \%$ that accepted with Akhmetsadykova et al. (2015) who accounted that the majority of LAB isolates were cocci $(70 \%)$ in camel milk.

The highest \% of LAB was recorded for Enterococcus spp. in different animal species especially in camel milk $(41.7 \%)$ that agreed with (Davati et al., 2015) who showed that, Enterococcus spp. were dominant in comparison with other LAB genus. Because of high salt presence in camel milk compared to other livestock animals, large numbers of Enterococcus spp. can live in camel milk.

Bovine mastitis produces a wide variety of problems in the dairy farms. The treatment of this disease is based on the use of antibiotics which are often unsatisfactory for its successful treatment. These drugs are also responsible for the presence of residues in the milk and the increase of antibiotic-resistant strains (Espeche et al., 2012). Multidrug resistant bacteria may arise as a result of selection pressure in cattle and other food animals, as a result of use of sub therapeutic doses of antibiotics in their feed. For the previous reasons alternative treatments are continually under investigation. Probiotic products are proposed as a valid alternative to antibiotic therapies and are also useful for the prevention of infectious syndromes (Beecher et al., 2009; Espeche et al., 2012 and Adeniyi et al., 2015). One of the important FAO/WHO (2002) criteria for the selection of organism for probiotic purpose is their ability to display antimicrobial activity against pathogenic bacteria. So that about 75 strains were selected from the four groups of LAB isolated from raw milk and were subjected to study their antibacterial effect on some bacteria that sharing as causing bovine mastitis including $S$. aureus and S. uberis; representing Gram positive bacteria and $E$. coli and Yersinia enterocolotica; representing Gram negative bacteria. Our result revealed that from the selected 30 of Enterococci 18-22 isolates had inhibitory effects on all of the mastitis causing bacteria with inhibition zone diameter ranged between 10-25 $\mathrm{mm}$ and from the selected 15 isolates of Leuconostocs 7-10 isolates had inhibitory effect on all of the mastitis causing bacteria with inhibition zone diameter ranged between 10-22 mm. Moreover from the selected 15 Pediococcus strains only 8-9 isolates showed inhibition zone diameter ranged between 10-20 mm for the four mastitis causing bacteria. Also from the selected 15 Streptococcus strains 9-12 isolates showed inhibition zone diameter ranged between 10$25 \mathrm{~mm}$ for $S$. aureus, S. uberis, E. coli and Yersinia enterocolotica.

In the explanation of their antibacterial activity, LAB can produce antimicrobial agents that exert strong antagonistic activity against many microorganisms, including pathogenic and spoilage microorganisms. Metabolites such as organic acids (lactic and acetic acid), hydrogen peroxide, ethanol, diacetyl, 
acetaldehyde, acetoine, carbon dioxide, reuterin, reutericyclin and bacteriocins, are examples of antimicrobial agents produced by LAB (Jagoda et al., 2010). Organic acid produced by LAB leads to a reduction in $\mathrm{pH}$ levels and increases the production of hydrogen peroxide (Ponce et al., 2008). These products exhibit antibacterial activity against various pathogenic microorganisms, including Gram-positive and Gram negative bacteria (Maragkoudakis et al., 2009).

Many studies were agreed with our previous results. Davati et al. (2015) revealed that most of the LAB isolated from camel milk can inhibit the growth of $S$. aureus, B. cereus and E. coli, because the clear zone of inhibition was $0.5 \mathrm{~mm}$ or larger. Daba and Saidi (2015) found that, from 12 strains of LAB isolated from raw milk only 5 isolates had effective inhibitory activity against S.aureus and two bacteriocinogenic isolates were effective against Gram-negative bacteria including Pseudomonas aeruginosa and E. coli. Henning et al. (2015) detected antimicrobial activity of 41 isolates of LAB included Leuconostoc mesenteroides, Pediococcus acidilactici, as well as Enterococcus faecium and Enterococcus hirae against L. monocytogenes.

In our antibacterial activity assay of the isolated LAB strains on mastitis causing bacteria we noticed that $E$. coli had the lower inhibition zone diameters. That phenomenon was noticed also by Daba and Saidi (2015) who attributed that to be due to the complexity of their cellular wall in comparison to Gram-positive bacteria, containing lipopolysaccharides (LPS) which are absent in Gram-positive bacteria.

Identifying species that produced antibacterial agents within the four genera by classical differential characteristics of physiological / biochemical nature revealed that, from 22 Enterococcus strains 14 were identified as Enterococcus hirae and 8 were identified as Enterococcus faecium. From 10 Leuconostoc strains 7 were identified as Leuconostoc mesenteroides. From 9 Pediococcus strains 5 were Pediococcus acidilactici and 4 were Pediococcus pentosaceus. Moreover all the 12 Streptococcus strains were identified as Streptococcus thermophilus. This study suggested raw milk of cows, goats and she-camels as a potential source for the isolation of probiotic LAB strains with antibacterial properties against pathogenic bacteria that cause bovine mastitis, because of their production of bacteriocin-like inhibitory substances.

In the point of view of probiotic potential, Espeche $e t$ al. (2012) pre-selected 40 LAB strains isolated from milk to perform their genetic identification based on the criteria described above. Only four different species were identified: Enterococcus hirae (45.0\%), Pediococcus pentosaceus (35.0\%), Weissella cibaria (17.5\%) and E. faecium (2.5\%). Most of the high hydrogen peroxide-producers $(63.0 \%)$ were identified as $P$. pentosaceus. All the bacteriocin-producers were identified as E. hirae. E. hirae and P. pentosaceus were the predominant species in samples obtained from healthy quarters. Recently, Henning et al. (2015) detected antimicrobial activity of 41 isolates of LAB included Leuconostoc mesenteroides, Pediococcus acidilactici, as well as Enterococcus faecium and Enterococcus hirae against $L$. monocytogenes. Davati et al. (2015) isolated E. durans, L. casei, E. lactis and P. pentosaceus from camel milk and selected them as probiotic bacteria. In another study on goat milk, de Almeida Júnior et al. (2015) concluded that the LAB included Enterococcus faecium isolated from goat milk have high potential for probiotic application, with elevated production of EPS, survival at low $\mathrm{pH}$ and confirmed in vitro inhibition of pathogens.

Several published studies illustrated the inaccurate and little ambiguous identification of various Gram positive pathogens by commercial and even API identification systems (Yeung et al., 2002; Winston et al., 2004 and Kulwichit et al., 2007). In order to validate the previous results, whole cell protein patterns were obtained using SDS-PAGE for these LAB strains and were analyzed by calculating the coefficients of similarity (>100) for 53 LAB strains that had antibacterial activity. As Sanchez et al. (2003) have observed that the SDS-PAGE technique generated complex and stable patterns that were easy to be interpreted and compared with the reference strains of LAB.

The present results showed that coefficient of similarity of $90.8 \%$ with the reference strain clarified the identity of the Leuconostoc mesenteroides. The dissimilarities between the identified isolates and the reference strain may be due to the different origin of the compared strains, as it was indicated by Samelis et al. (1995) and Pérez et al. (2000).

The protein analysis confirmed the phenotypic identification for most isolates that were identified as Pediococcus acidilactici with a percentage of similarity $92.5 \%$. On the other hand, a notable similarity was observed between biochemical identification and SDS-PAGE profiles for isolates that were phenotypically identified as Streptococcus thermophilus (similarity 99.89\%). This result came in parallel with that of Jarvis and Wolff (1979) who used gel electrophoretic patterns of proteins in bacterial cell extracts to group strains of lactic streptococci according to their overall similarity. They added that grouping of bacteria by gel electrophoretic protein patterns correlated well with results obtained by DNA hybridization and with numerical taxonomy. The data they presented showed that such strains were likely to have a high overall similarity. Moreover, Guimont et al. (1994) reported that electrophoresis was shown to discriminate $S$. 
thermophilus from other bacteria such as L. lactis or Enterococci screened in their laboratory. They suggested that, the protein patterns of S. thermophilus presented a high similarity, confirmed with 5 others strains. Here we can record that gel electrophoretic patterns of soluble cell extracts can therefore be used to determine which strains of lactic streptococci were most similar to one another in overall genotype, as determined by their relative position in the resulting dendrogram (Computerized comparisons of electrophoretic protein patterns).

Our results clearly revealed that the strains that were biochemically identified as Enterococcus hirae have shown a high level of similarity with (99.84\%). However, the findings of our study generally suggested that the analysis of whole-cell protein profiles provided an effective method for confirming and distinguishing the closely related LAB isolates. These findings seem to be in agreement with those obtained by Rowaida et al. (2007) who concluded that the isolates of $\mathrm{LAB}$ isolated from faeces of breast-fed infants in Egypt were identified using the API system for primary identification and SDSPAGE protein patterns for confirmation.

In this study we concluded that the biochemical tests were so longer and may be unsatisfactory for the identification of isolated LAB and that the use of SDS-PAGE method had allowed the clarification of some ambiguous points in phenotypic identification. For example, separation between strains which have closer phenotypic profiles, resolved the problem of microscopic determination of cell shape. Consequently, our results showed that, protein fingerprinting analysis corroborated, completed and confirmed the phenotypic identification. Therefore, protein electrophoresis SDS-PAGE had allowed the separation of strains possessing very high or similar phonotypical profiles and these results came in accordance with El Soda et al. (2003) and De Vuystand Vancanneyt (2006) who recorded that the SDS-PAGE technique confirmed $94 \%$ of the API identification results as in our results there were high Coefficient of similarities ranged between $90.8 \%$ for Leuconostoc spp. to $99.8 \%$ for Streptococcus thermophilus and Enterococci spp. Also Cheriguene et al. (2007) mentioned that, the identification based on biochemical tests or even by the API system led sometimes to false results, or sometimes did not allow for identification of the strain and that the use of SDS-PAGE made it possible to determine the electrophoretic profile of the strains and confirmed $75 \%$ of the their obtained results.

Microorganisms to be applied as probiotics require a reliable identification by using a molecular method (FAO-WHO, 2002), so we selected representative strains of Enterococci as they were the most isolated group of LAB in this study and gave the higher antibacterial activity against bacterial mastitis pathogens. The obtained sequences of these isolates were submitted to the Gen Bank database with the following accession numbers KU847974 and KU847975 for E. faecium and E. hirae, respectively. This provided more accurate sequence-based identification. Many researches ensured the accuracy of sequence-based identification of LAB that agreed with our results (Bosshard et al., 2006; Kulwichit et al., 2007; Henning et al., 2015).

Finally we recommend using numerical analysis of phenotypic methods, gel electrophoretic patterns of the proteins and molecular methods in the closely related $\mathrm{LAB}$ to distinguish between species and to group strains within a species according to their similarities as it has the ability to store a large number of patterns in databanks for reference.

\section{CONCLUSION}

This study suggested that raw animal milk may be a potential source for the isolation of probiotic LAB strains and can be considered good for health with antibacterial properties against pathogenic bacteria. Bacteriocin like substances produced by some LAB active against mastitis pathogens may be presented as an interesting alternative to antibiotic drugs to overcome the antibiotic resistance of mastitis pathogens as well as antibiotic residues in milk. Further researches are needed to identify compounds produced by the selected LAB, their purification and sequencing. This type of work is in progress in our veterinary laboratories.

\section{REFERENCES}

Abbasiliasi, S.; Tan, J.S.; Ibrahim, T.A.T.; Ramanan, R.N.; Vakhshiteh, F.; Mustafa, S.; Ling, T.C.; Abdul Rahim, R. and Ariff, A.B. (2012): Isolation of Pediococcus acidilactici Kp10 with ability to secrete bacteriocin-like inhibitory substance from milk products for applications in food industry. BMC Microbiology, 12, 260: $12 \mathrm{p}$.

Adeniyi, B.A.; Adetoye, A. and Ayeni, F.A. (2015): Antibacterial activities of lactic acid bacteria isolated from cow faeces against potential enteric pathogens. Afr. Health Sci.;15 (3): 888-95.

Akhmetsadykova, S.H.; Baubekova, A.; Konuspayeva, G.; Akhmetsadykov, N.; Faye, B. and Loiseau, $G$. (2015): Lactic acid bacteria biodiversity in raw and fermented camel milk. Afr. J. Food Sci. Technol., 6(3): 84-88.

Aziz, T.; Khan, H.; Bakhtair, S.M. and Naurin, M. (2009): Incidence and relative abundance of lactic acid bacteria in raw milk of buffalo, cow and sheep. The J. Anim. Plant Sci., 19(4): 168-173. 
Beecher, C.; Daly, M.; Berry, D.P.; Klostermann, K.; Flynn, J. and Meaney, W. (2009): Administration of a live culture of Lactococcus lactis DPC 3147 into the bovine mammary gland stimulates the local host immune response, particularly IL-1 and IL-8 gene expression. J. Dairy Res.; 76: 340-8.

Bosshard, P.P.; Zbinden, R.; Abels, S.; Böddinghaus, B.; Altwegg, M. and Böttger, E.C. (2006): 16s RRNA gene sequencing $v s$. the API $20 \mathrm{NE}$ system and the VITEK 2 ID-GNB card for identification of non fermenting Gramnegative bacteria in the clinical laboratory. $\mathrm{J}$. Clin. Microbiol, 44: 1359-1366.

Cheriguene, A.; Chougrani, F.; Bekada, A.M.A.; El Soda, M. and Bensoltane, A. (2007): Enumeration and identification of lactic microflora in Algerian goats' milk. Afr. J. Biotechnol., 6 (15): 1854-1861.

Daba, H. and Saidi, S. (2015): Detection of bacteriocin-producing lactic acid bacteria frommilk in various farms in north-east Algeria by a new procedure. Agronomy Res., 13(4), 907-918.

Darsanaki, R.K.; Rokhi, M.L.; Aliabadi, M.A. and Issazadeh, K. (2012): Antimicrobial Activities of Lactobacillus Strains Isolated from Fresh Vegetables. Middle-East J. Scientific Res., 11 (9): 1216-1219.

Davati, N.; Yazdi, F.T.; Zibaee, S.; Shahidi, F. and Edalatian, M.R. (2015): Study of lactic acid bacteria community from raw milk of Iranian one humped camel and evaluation of their probiotic properties. Jundishapur J. Microbiol.; 8(5): 16750.

De Almeida Júnior, W.L.G.; da Silva Ferrari, I.; de Souza, J.V.; da Silva, C.D.A.; da Costa, M.M. and Dias, F.S. (2015): Characterization and evaluation of lactic acid bacteria isolated fromgoat milk. Food Control. 53: 96-103.

De Vuyst, L. and Vancanneyt, M. (2006): Biodivrsity and identification of sourdough lactic acid bacteria. Food. Microbiol., 24(2): 120-127.

El Soda, M.; Ahmed, N.; Omran, N.; Osman, G. and Morsi, A. (2003): Isolation, identification and selection of lactic acid bacteria cultures for cheese making. Emir. J. Agric. Sci., 15 (2): 51 71.

Espeche, M.C.; Otero, M.C.; Sesma, F. and NaderMacías, M.E.F. (2009): Screening of surface properties and antagonistic substances production by lactic acid bacteria isolated from the mammary gland of healthy and mastitic cows. Vet. Microbiol.; 135: 346-57.

Espeche, M.C.; Pellegrino, M.; Frola, I.; Larriestra, A.; Bogni, C. and Nader-Macías, M.E.F. (2012): Lactic acid bacteria from raw milk as potentially beneficial strains to prevent bovine mastitis. Anaerobe 18: 103-109.

Food and Agriculture Organization/World Health Organization. (2002): Guidelines for the evaluation of probiotics in food. Report of a Joint FAO/WHO Working Group on Drafting Guidelines for the Evaluation of Probiotics in Food; Ontario, Canada. April 30, May 1.

Ghazi, F.; Henni, D.E.; Benmechernene, Z. and Kihal, M. (2009): Phenotypic and whole cell protein analysis by SDS-PAGE for identification of dominants lactic acid bacteria isolated from algerian raw milk. World J. Dairy \& Food Sci., 4 (1): 78-87.

Giannino, M.L.; Aliprandi, M.; Feligini, M.; Vanoni, L.; Brasca, M. and Fracchetti, F. (2009): A DNA array based assay for the characterization of microbial community in raw milk. J. Microbiol. Methods.78: 181-8.

Guessas, B. and Kihal, M. (2005): Characterization of lactic acid bacteria isolated from Algerian arid zone raw goats' milk. Afr. J. Biotechnol., 3: 339-342.

Guimont, C.; Clary, O. and Bracquart, P. (1994): Analysis of whole-cell proteins of Streptococcus thermophilus by 2 electrophoretic methods. Lait., 74: 13-21.

Henning, C.; Vijayakumar, P.; Adhikari, R.; Jagannathan, B.; Gautam, D. and Muriana, P.M. (2015): Isolation and taxonomic identity of bacteriocin-producing lactic acid bacteria from retail foods and animal sources. Microorganisms, 3: 80-93.

Jagoda, S.; Kos, B.; Beganovic, J.; Pavunc, A.L.; Habjanic, $K$. and Matosic, S. (2010): Antimicrobial activity of lactic acid bacteria, Food Technol. Biotechnol.; 48 (3): 296-307.

James, G. (2010): Universal bacterial identification by PCR and DNA sequencing of $16 \mathrm{~S}$ rRNA gene. In: PCR for Clinical Microbiology, Schuller, M., T.P. Sloots, G.S. James, C.L. Halliday and I.W.J. Carter (Eds.). Springer, New York, USA. 209-214.

Jarvis, A.W. and Wolff, J.M. (1979): Grouping of lactic Streptococci by gel electrophoresis of soluble cell extracts. Applied and Environ. Microbiol., 37(3): 391-398.

Knoll, C.; Divol, B. and du Toit, M. (2008): Genetic screening of lactic acid bacteria of oenological origin for bacteriocin-encoding genes. Food Microbiol., 25, 983-991.

Kulwichit, W.; Nilgate, S.; Chatsuwan, T.; Krajiw, S.; Unhasuta, C. and Chongthaleong, A. (2007): Accuracies of leuconostoc phenotypic identification: A comparison of API systems and conventional phenotypic assays. BMC Infect. Dis. 7: 69.

Lyon, W.J. and Glatz, B.A. (1993): Isolation and purification of propionicin PLG-1, a bacteriocin produced by a strain of Propionibacterium thoenii. Appl. Environ. Microbiol, 59: 83-88.

Macwana, S.J. and Muriana, P.M.A. (2012): "bacteriocin pcr array" for identification of bacteriocin-related structural genes in lactic 
acid bacteria. J. Microbiol. Methods. 88: 197-204.

Maragkoudakis, P.A.; Mountzouris, K.C.; Psyrras, D.; Cremonese, S.; Fischer, J.; Canter, M.D. and Tsakalidou, E. (2009): Functional properties of novel protective lactic acid bacteria and application in raw chicken meat against Listeria monocytogenes and Salmonella enteridis. Int. J. Food Microbiol., (130)3: 219- 226.

Miles, H.; Lesser, W. and Sears, P. (1992): The economic implications of bioengineered mastitis control. J. Dairy Sci., 75: 596-605.

Morrow, L.E.; Gogineni, V. and Malesker, M.A. (2012): Probiotics in the intensive care unit. Nutr. Clin. Prac., 27(2): 235-241.

Nader-Macías, M.E.F.; Otero, M.C.; Espeche, M.C. and Maldonado, N.C. (2008): Advances in the design of probiotic products for the prevention of major diseases in dairy cattle. J. Ind. Microbiol. Biotechnol., 35:1387-95.

Nikita, C. and Hemangi, D. (2012): Isolation, identification and characterization of lactic acid bacteria from dairy sludge sample.J. Environ. Res. Develop. 7(1A): 234-244.

Ogier, J.C.; Son, O.; Gruss, A.; Tailliez, P. and Delacroix-Buchet, A. (2002): Identification of bacterial microflora in dairy products by temporal temperature gradient gel electrophoresis. J. Appl. Environ. Microbiol., 68(8): 3691-701.

O’Sullivan, O.; O'Callaghan, J.; Sangrador-Vegas, A.; McAuliffe, O., Slattery, L. and Kaleta, P. (2009): Comparative genomics of lactic acid bacteria reveals a nichespecific gene set. BMC Microbiol., 9: 1-9.

Patil, M.M.; Pal, A.; Anand, T. and Ramana, K.V. (2010): Isolation and characterization of lactic acid bacteria from curd and cucumber. Ind. J. Biotechnol., 9: 166-72.

Pérez, G., Cardell, E. and Zarate, V. (2000): Protein fingerprinting as a complementary analysis to classical phenotyping for the identification of lactic acid bacteria from Tenerife cheese. Lait, 80: 589-600.

Ponce, A.G.; Moreira, M.R.; Valle, C.E. and Roura, S.I. (2008): Preliminary characterization of bacteriocinlike substance from lactic acid bacteria isolated from organic leafy vegetables. Food Sci. Technol., (41)3: 432-441.

Pot, B.; Vandamme, P. and Kersters, K. (1994): Analysis of electrophoretic whole organism protein fingerprints, In: M. Good fellow and A. G. O’Donnell (Eds). Pp 493-521. Chemical Methods in Prokaryotic Systematics. J. Wiley and Sons Limited Ltd. Chichester, NH.

Rodriguez-Palacios, A.; Staempfli, H.R.; Duffield, T. and Weese, J.S. (2009): Isolation of bovine intestinal Lactobacillus plantarum and Pediococcus acidilactici with inhibitory activity against Escherichia coli $\mathrm{O} 157$ and F5. J. Appl. Microbiol., 106: 393-401.

Rowaida, K.; Hoda, M.; El-Halafawy, K.; Kamaly, K.; Frank, J. and El Soda, M. (2007): Evaluation of the probiotic potential of lactic acid bacteria isolated from faeces of breast-fed infants in Egypt. Afr. J. Biotechnol., 6 (7): 939-949.

Samelis, J.; Tsakalidou, E.; Metaxopoulos, J. and Kalantzopoulos, G. (1995): Differenciation of Lactobacillus sake and Lactobacillus curvatus isolated from naturally fermented Greek dry salami by SDS-PAGE of whole cell proteins. J. Appl. Bacteriol., 78, 157-163.

Sanchez, I.; Sesena, S. and Palop, L. (2003): Identification of lactic acid bacteria from spontaneous fermentation of 'Almagro' eggplant by SDS-PAGE whole cell protein fingerprinting. Int. J. Food Microbiol., 2555: 181-189.

Silva, G.S.; Ferrari, I.S.; Silva, C.D.A.; Almeida Júnior, W.L.G.A.; Carrijo, K.F. and Costa, M.C. (2013): Microbiological and physicalchemical profile of goat milk in the semiarid region of the San Francisco Valley. Veterinaria Notícias, 19(1): 14-22.

Stiles, M.E. and Holzapfel, W.H. (1997): Lactic acid bacteria of foods and their current taxonomy. Int. J. Food Microbiol., 36(1): 1-29.

Sun, P.; Wang, J.Q. and Zhang, H.T. (2010): Effects of Bacillus subtilis natto on performance and immune function of preweaning calves. J. Dairy Sci., 93: 5851-5.

Tamura, K.; Peterson, D.; Peterson, N.; Stecher, G.; Nei, M. and Kumar, S. (2011): MEGA5: Molecular evolutionary genetics analysis using maximum likelihood, evolutionary distance, and maximum parsimony methods. Mol. Biol. Evol., 28, 2731-2739.

Van den Berg, D.J.C.; Smith, A.; Pot, B.; Ledeboer, A.M.; Kerstens, K.; Verbakel, J.M.A. and Verrips, C.T. (1993): Isolation, screening and identification of lactic acid bacteria from traditional food fermentation processes and culture collections. Food biotechnol., 7:189205.

Winston, L.G.; Pang, S.; Haller, B.L.; Wong, M.; Chambers, H.F. $3^{\text {rd }}$; Perdreau-Remington, F. (2004): API 20 strep identification system may incorrectly speciate enterococci with low level resistance to vancomycin. Diagn Microbiol Infect. Dis., 48(4): 287-288.

Yeung, P.S.; Sanders, M.E.; Kitts, C.L.; Cano, R. and Tong, P.S. (2002): $\quad$ Species-specific identification of commercial probiotic strains. J. Dairy Sci., 85(5): 1039-1051. 


\title{
الخصائص الظاهريه والتصنيف الجزيئى لبعض البكتيريا المنتجه لحمض اللاكتيك فى اللبن الخام لأنواع الحيوانات لإنفئ المختلفه

\author{
هناء عبد المنعم عبد الفتاح عصفور ، إيناس محمد جمال اللدين ، سعاح فكرى درويش
}

E-mail: hanaaasfour@yahoo.com Assiut University web-site: $\underline{\text { www.aun.edu.eg }}$

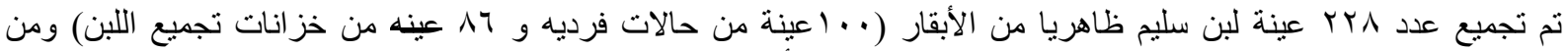

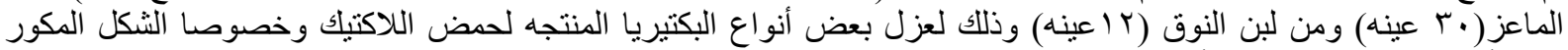

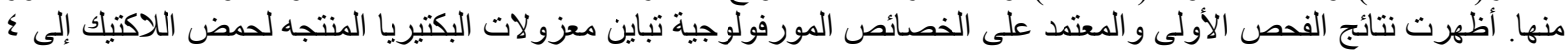

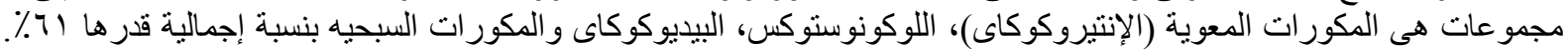

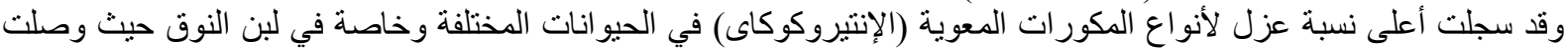

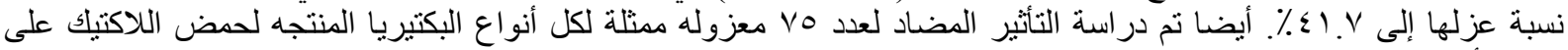

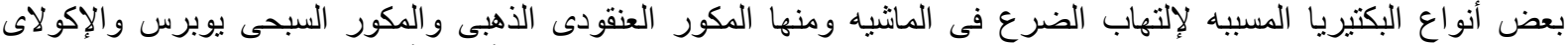

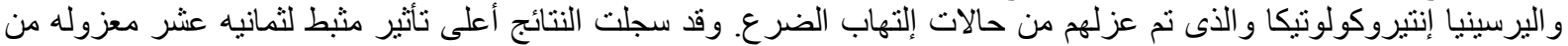

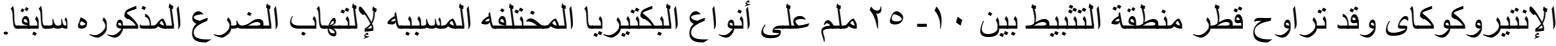

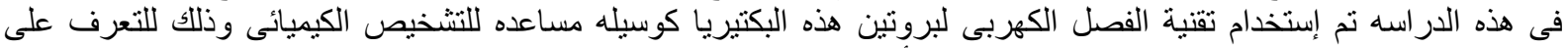

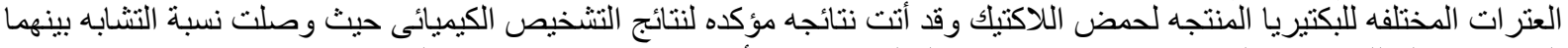

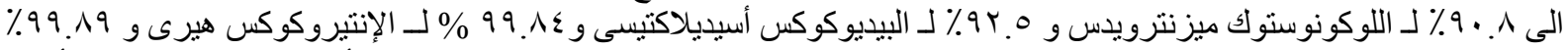

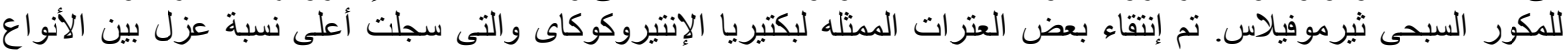

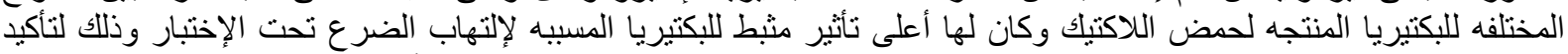

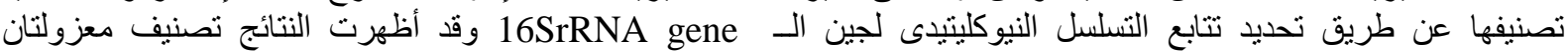

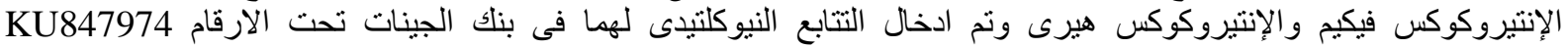

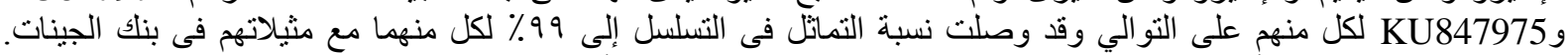

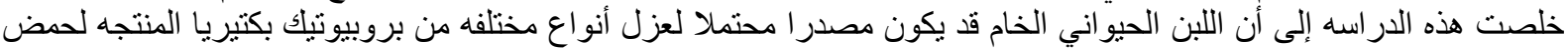

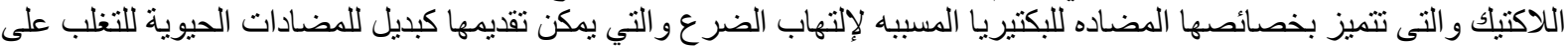

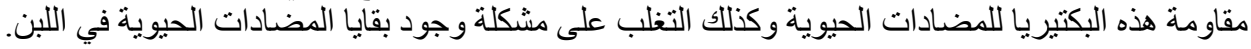

